\title{
The range of the golden-mantle tamarin, Saguinus tripartitus (Milne Edwards, 1878): distributions and sympatry of four tamarin species in Colombia, Ecuador, and northern Peru
}

\author{
Anthony B. Rylands • Christian Matauschek • Rolando Aquino • \\ Filomeno Encarnación • Eckhard W. Heymann - Stella de la Torre • \\ Russell A. Mittermeier
}

Received: 17 June 2010/ Accepted: 5 August 2010/Published online: 29 September 2010

(C) The Author(s) 2010. This article is published with open access at Springerlink.com

\begin{abstract}
A detailed understanding of the range of the golden-mantle tamarin, Saguinus tripartitus (Milne Edwards, 1878), in Amazonian Peru and Ecuador is of particular relevance, not only because it is poorly known but also because it was on the basis of its supposed sympatry with the saddleback tamarin (S. fuscicollis lagonotus) that Thorington (Am J Primatol 15:367-371, 1988) argued that it is a distinct species rather than a saddleback tamarin subspecies, as was believed by Hershkovitz (Living new world monkeys, vol I. The University of Chicago Press, Chicago, 1977). A number of surveys have been carried out since 1988 in the supposed range of $S$. tripartitus, in both Ecuador and Peru. Here we summarize and discuss these issues and provide a new suggestion for the geographic range of this species; that is, between the ríos Napo and Curaray in Peru and extending east into Ecuador. We also
\end{abstract}

\footnotetext{
A. B. Rylands $(\bowtie) \cdot$ R. A. Mittermeier

Conservation International, 2011 Crystal Drive,

Suite 500, Arlington, VA 22202, USA

e-mail: a.rylands@conservation.org

C. Matauschek · E. W. Heymann

Abteilung Verhaltensoekologie, Deutsches Primatenzentrum,

Kellnerweg 4, 37077 Göttingen, Germany

R. Aquino

C. I. Instituto Veterinario de Investigaciones Tropicales

y de Altura, Universidad Nacional Mayor,

Apartado 575, Iquitos, Loreto, Perú

F. Encarnación

Ecología y Vegetación Amazónica,

Jr. Tacna 620, Iquitos, Perú

S. de la Torre

College of Life Sciences, Universidad San Francisco de Quito,

Av. Interoceánica, Quito, Ecuador
}

review current evidence for the distributions of Spix's black-mantle tamarin ( $S$. nigricollis nigricollis), Graells' black-mantle tamarin ( $S . n$. graellsi), and the saddleback tamarin (S. fuscicollis lagonotus), which are also poorly known, and examine the evidence regarding sympatry between them. We conclude that despite the existence of a number of specimens with collecting localities that indicate overlap in their geographic ranges, the fact that the four tamarin species are of similar size and undoubtedly very similar in their feeding habits militates strongly against the occurrence of sympatry among them.

Keywords Callitrichidae - Tamarin - Saguinus . Taxonomy $\cdot$ Distribution $\cdot$ Sympatry $\cdot$ Northwestern Amazon

\section{Introduction}

The golden-mantle tamarin, Saguinus tripartitus (Milne Edwards, 1878), of the western Amazon, was one of the 14 subspecies of saddleback tamarin, S. fuscicollis (Spix, 1823) proposed in the taxonomy of Hershkovitz (1977). Thorington (1988) showed that that the information concerning its geographic distribution was scarce and confused but, following a reappraisal of the evidence, he argued that it was in fact a full species due to its sympatry with the redmantle saddleback tamarin, S. fuscicollis lagonotus. Since this publication, a number of surveys have been carried out in Ecuador (Albuja 1994; de la Torre 1996) and Peru (Encarnación et al. 1990; Aquino and Encarnación 1996; Heymann 2000; Heymann et al. 2002; Aquino et al. 2005; Matauschek in prep.; Aquino unpublished data). Here we summarize the information obtained in these surveys and propose new boundaries for the geographic range of this 
species. We also examine the evidence regarding sympatry with $S$. fuscicollis, as well as with Graells' black-mantle tamarin (S. nigricollis graellsi) and Spix's black-mantle tamarin (S. nigricollis nigricollis).

\section{Distribution of $S$. tripartitus}

The distribution of $S$. tripartitus has been in doubt for many decades. The type of Midas tripartitus Milne Edwards, 1878, is a skin of a female in the Museum National d'Histoire Naturelle in Paris [No.122 653(633A. 1877-562)], and the type locality is Río Napo, Oriente, Ecuador (Hershkovitz 1977; Groves 2001). De Ávila-Pires (1974) proposed that the species occurs along the north bank of the Río Amazonas right up to the mouth of the Río Putumayo-Içá in Brazil. Apparently supporting this, Hernández-Camacho and Cooper (1976, p. 39; see also Hernández-Camacho and Defler 1985) reported that
S. fuscicollis is not known in the immediate region of Leticia (on the Río Amazonas, north bank, in the Colombian trapezium), but that they had examined specimens "referable to S. fuscicollis tripartitus" in Leticia, which were reportedly from the Colombian bank of the Río Amazonas; Puerto Nariño by the Quebrada Pichuna Yacú, upstream of Leticia (Fig. 1). Neville (1976) and Freese et al. (1982) reported that they found only S. nigricollis during surveys along the Río Ampiyacu north of the Río Amazonas near Colombia, in Peru (Fig. 1). Hershkovitz (1977) concluded that S. tripartitus occurred between the Ríos Putumayo (right bank) and Napo (left bank), west to the Andes in Peru and Ecuador, and east to beyond the confluence of the Río Napo with the Río Amazonas.

Defler (2004) mentioned that the occurrence of S. tripartitus between the Ríos Putumayo and Amazonas in Colombia had still to be confirmed. In more recent surveys, Montenegro and Escobedo (2004), like Neville (1976),

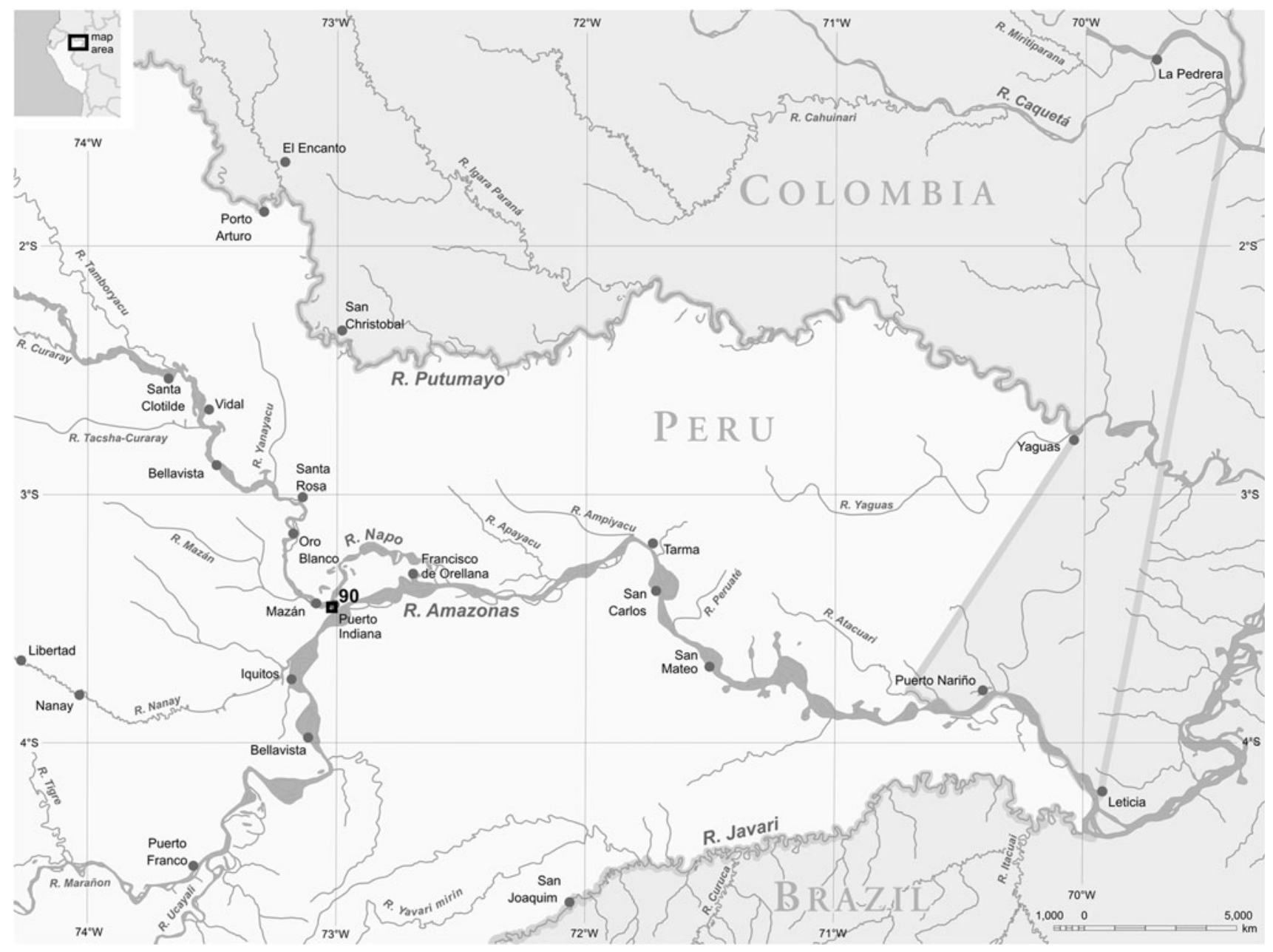

Fig. 1 The western Amazon, including southern Colombia, northeastern Peru, and Brazil. Locality 90 is Puerto Indiana, cited as the north bank Río Marañon and a locality for Saguinus tripartitus and
S. fuscicollis lagonotus by Hershkovitz (1977). See Table 1. Map (C) Kellee Koenig/Conservation International 
found only $S$. nigricollis (presumed by them to be $S$. $n$. nigricollis) at survey sites along the Ríos Ampiyacu and Apayacu (a little to the west of Ampiyacu) but recorded $S$. nigricollis and a saddleback tamarin (S. fuscicollis) at sites a little east on the Río Yaguas (Fig. 1). They made no mention of $S$. tripartitus, and one could suppose that the saddleback tamarin they saw is an undescribed subspecies [S. f. fuscus occurs to the north of the Putumayo and S. f. nigrifrons to the south of the Río Amazonas (Aquino and Encarnación 1994; Defler 2004)]. S. tripartitus has never been recorded in Brazil].

Hershkovitz's (1977) belief that it occurred north of the Río Napo east as far as the Río Amazonas in Peru was based on specimens collected by Carlos Olalla and his sons in 1926 and labelled "Puerto Indiana", a town on the left bank of the Río Amazonas, approximately $40 \mathrm{~km}$ north of Iquitos. Hershkovitz (1977) placed Puerto Indiana north of the Río Marañon (Amazonas) just downstream of the mouth of the Río Napo (Fig. 1; Table 1) but, as pointed out by Thorington (1988), Puerto Indiana is, in fact, on the left bank of the Rio Amazonas upstream of the mouth of the Río Napo (Fig. 1). Puerto Indiana is also a locality for $S$. $f$. lagonotus (see Table 1), and for this reason, Thorington (1988) concluded that: (1) S. tripartitus occurs on the right bank of the lower Río Napo at its mouth [not the left bank, as argued by Hershkovitz (1977)], and (2) that, occurring on the right bank, it is sympatric with $S$. f. lagonotus, and therefore must be considered a distinct species. Thorington (1988) also believed that a further two localities identified by Hershkovitz (1977) — the mouth of the Curaray [south of the Napo, locality 80, gazetteer p. 928, Fig XIII.4 on page 916 in Hershkovitz (1977); see Table 1; Fig. 1], and San Francisco [north of the Napo, locality 66, gazetteer p. 927, Fig XIII.4 on page 916 in Hershkovitz (1977); see Table 1;

Table 1 The five localities of Saguinus fuscicollis tripartitus listed by Hershkovitz (1977)

\begin{tabular}{|c|c|c|}
\hline & Hershkovitz (1977) & Notes \\
\hline 66 & $\begin{array}{l}\text { San Francisco, Río Napo, left bank, } 0^{\circ} 30^{\prime} \mathrm{S}, 76^{\circ} 22^{\prime} \mathrm{W} \\
\text { S. fuscicollis tripartitus } \\
\text { P. Hershkovitz, February-March 1936, on left bank at } 200 \mathrm{~m} \\
\text { S. nigricollis graellsi } \\
\text { P. Hershkovitz, February-March 1936, on right bank at } 200 \mathrm{~m}\end{array}$ & $\begin{array}{l}\text { North of the Rio Napo. The proximity of the locality of Coca (also } \\
\text { Francisco de Orellana) that is the type locality of } S \text {. f. lagonotus } \\
\text { indicated sympatry, and comprised part of the argument of } \\
\text { Thorington (1988) that tripartitus should be considered a distinct } \\
\text { species } \\
\text { See Fig. } 2\end{array}$ \\
\hline $67 \mathrm{a}$ & $\begin{array}{l}\text { Lagarto Cocha, mouth, } 0^{\circ} 39^{\prime} \mathrm{S}, 75^{\circ} 16^{\prime} \mathrm{W} \\
\text { S. nigricollis graellsi } \\
\text { Olalla Bros., January } 1926 \\
\text { S. fuscicollis tripartitus } \\
\text { Olalla Bros., January } 1926\end{array}$ & $\begin{array}{l}\text { North of the Río Napo. The Lagartococha is tributary of the Río } \\
\text { Aguarico which enters the Río Napo from the north } \\
\text { See Fig. } 2\end{array}$ \\
\hline $67 \mathrm{~b}$ & $\begin{array}{l}\text { Aguarico (Río), } 0^{\circ} 59^{\prime} \mathrm{S}, 75^{\circ} 11^{\prime} \mathrm{W} \\
\text { S. fuscicollis tripartitus } \\
\text { Olalla Bros., January } 1924 \text {, December } 1925\end{array}$ & $\begin{array}{l}\text { North of the Río Napo. Napier (1976) lists the two specimens as } \\
\text { follows: } \\
\text { 1. 1934.9.10.23. Male adult, skin, skull. "Oriente, near the R. } \\
\text { Napo, } 2000-3000 \text { ft." January } 1924 \\
\text { 2. 1934.9.10.24. Male adult, skin, skull, slide of hair. "Oriente, } \\
\left.\text { near Aguarico [0, } 76^{\circ} 20^{\prime} \mathrm{W}\right], 2000 \mathrm{ft} . " \text { December } 1925 \\
\text { See Fig. } 2\end{array}$ \\
\hline 80 & $\begin{array}{l}\text { Curaray (Río) (mouth), } 2^{\circ} 22^{\prime} \mathrm{S}, 74^{\circ} 05^{\prime} \mathrm{W}, 140 \mathrm{~m} \\
\text { S. fuscicollis tripartitus } \\
\text { Olalla Bros., October-December } 1925 \\
\text { S. fuscicollis lagonotus } \\
\text { Olalla Bros., May } 1926 \\
\text { S. fuscicollis graellsi } \\
\text { Olalla Bros., } 1925\end{array}$ & $\begin{array}{l}\text { South of the Río Napo. The Río Curaray is a right-bank tributary } \\
\text { of the lower Río Napo. Thorington (1988) inferred that } S . f \text {. } \\
\text { lagonotus and } S . f \text {. tripartitus were sympatric at this locality } \\
\text { See Fig. } 2\end{array}$ \\
\hline 90 & $\begin{array}{l}\text { Puerto Indiana, Río Marañon, north bank, } 3^{\circ} 20^{\prime} \mathrm{S}, 72^{\circ} 40^{\prime} \mathrm{W}, 100 \mathrm{~m} \\
\text { S. fuscicollis tripartitus } \\
\text { Olalla Bros., May, June, July } 1926 \\
\text { S. fuscicollis lagonotus } \\
\text { Olalla Bros., August } 1926\end{array}$ & $\begin{array}{l}\text { South of the Río Napo. As pointed out by Thorington (1988), } \\
\text { Puerto Indiana is in fact on the left bank of the Río Marañon } \\
\text { (Amazonas) above the mouth of the Río Napo. The apparent } \\
\text { sympatry of the two subspecies comprised part of the argument } \\
\text { of Thorington (1988) that tripartitus should be considered a } \\
\text { distinct species } \\
\text { See Fig. } 1\end{array}$ \\
\hline
\end{tabular}

Numbers in the left hand column are those used by Hershkovitz (1977, pp. 927-928, and map p. 916). See Figs. 1 and 2 
Fig. 2] — confirmed sympatry between the saddleback tamarins tripartitus and lagonotus (Table 1).

This confusion stimulated Aquino and Encarnación (1996) to investigate the Napo basin specifically to clarify the distributions of $S$. tripartitus and S. f. lagonotus. The results were surprising. They were unable to find any evidence at all for the occurrence of $S$. tripartitus along either bank of the lower Río Napo. Their survey included Puerto Indiana, the localities of Francisco de Orellana and Mazán nearby, as well as the left-bank tributaries of the Río Amazonas west of Puerto Indiana, the Ríos Ampiyacu, Apayacu, Peruaté, and Atacuarí, and tributaries on the left (Río Yanayacu) and right (Río Tacsha-Curaray) banks of the lower Río Napo (Fig. 1). In none of these areas were they able to locate $S$. tripartitus or find any evidence of its occurrence there. On the Río Mazán, a tributary entering the Río Amazonas upstream (west) of the Río Napo (Fig. 1), they found only S. f. lagonotus and S. n. graellsi. They considered, and discarded, the possibility that
S. tripartitus had become extinct in the area and were forced to the conclusion that the locality attributed by the Olalla Bros. (Puerto Indiana) was not where the type had been collected. On the same expedition (1925/1926) that included Puerto Indiana, the Olalla Bros. also collected and purchased animals and specimens along and from the Río Curaray, an upstream tributary of the Río Napo (Table 1), where the occurrence of S. tripartitus was confirmed by Aquino and Encarnación $(1994,1996)$ and later by Heymann (2000), Heymann et al. (2002), and Aquino et al. (2005).

From the surveys of Aquino and Encarnación (1996), Heymann (2000), Heymann et al. (2002), Aquino et al. (2005), and Aquino (this paper), it is now evident that in Peru, S. tripartitus occurs on the right bank of the Río Napo only west from the mouth of the Río Curaray (Fig. 2). Aquino et al. (2005) registered 14 groups in three localities in the basin of the Río Aushiri (mainstream and tributary Rio San José) (Fig. 2). Based on a sighting of one group

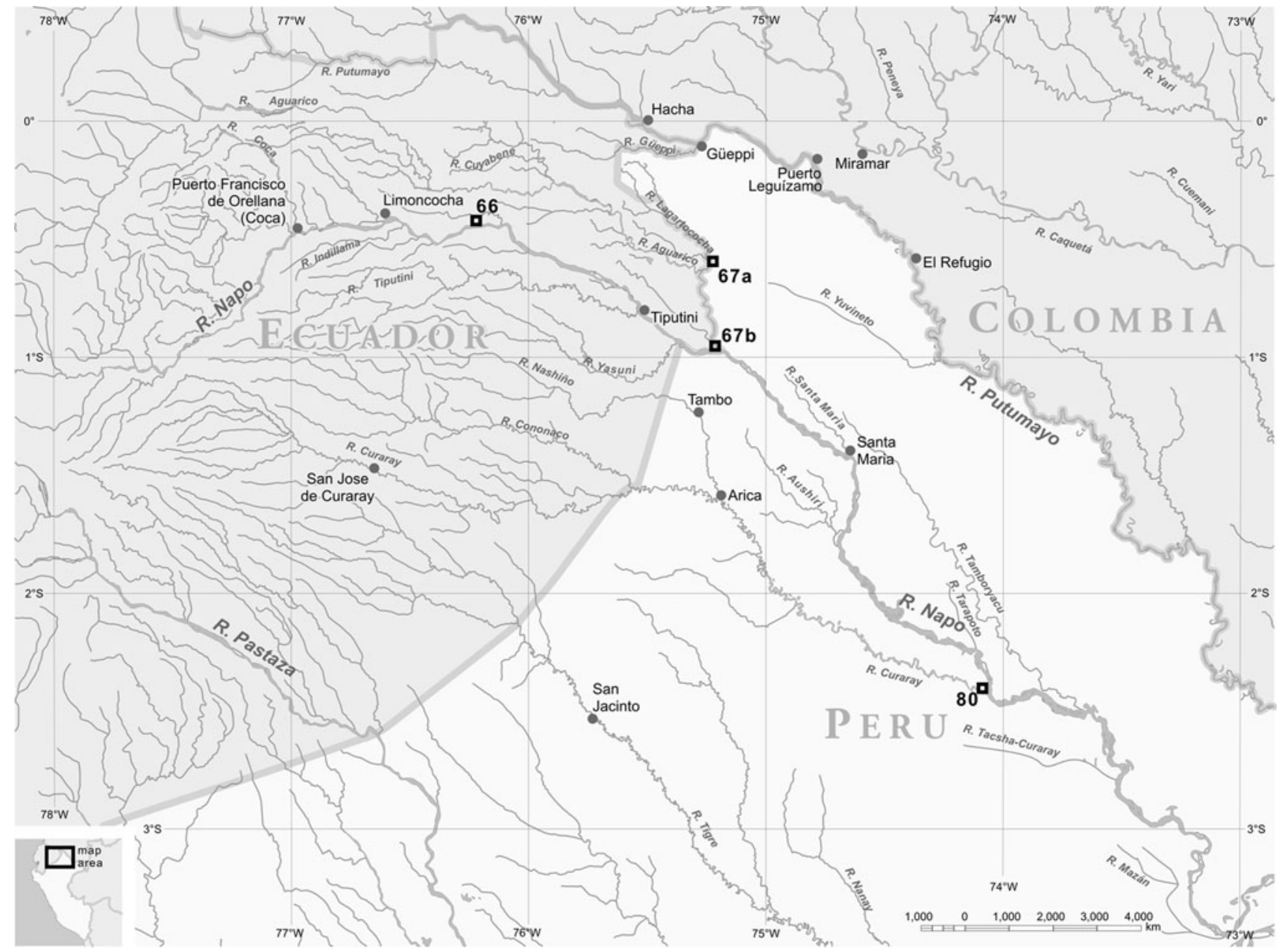

Fig. 2 The western Amazon, including eastern Ecuador, southern Colombia, and northeastern Peru. For an explanation of localities 66, 67a, 67b, and 80, see Table 1. Map (c) Kellee Koenig/Conservation International 
on the south (right) bank of the lower Río Yuvineto (Encarnación et al. 1990), Aquino and Encarnación (1996) concluded that the distribution of $S$. tripartitus extends to the left bank of the Río Napo only along the upper reaches of the Río Santa Maria, a northern (left-bank) tributary of the Napo, and from there north to the Río Putumayo on the Colombian border, and in the west as far as the right bank of the Río Güeppi and left bank of the Río Lagartococha (Fig. 2). However, C. Matauschek (in prep.) was unable to find S. tripartitus on the left (north) bank of the Napo along its entire course in Peru. Interviews of settlers at different locations along the course of the Napo showed that they did not know of $S$. tripartitus north of the Napo, confirming its presence only south of the Napo.

The northern limit to the distribution in Peru could be the Río Putumayo, but the evidence denies its occurrence north of the Río Napo in Ecuador. There, Albuja (1994) reported that it is restricted to the left bank of the Río Curaray, north to and not beyond the lower reaches of the Río Napo in Ecuador, but limited to the Río Tiputini (a right-bank tributary of the Napo) further west. Hershkovitz (1977), on the other hand, reported it from the left (north) bank of the Río Napo at the locality of San Francisco [two specimens in the University of Michigan Museum of Zoology, collected by Hershkovitz in 1936 (locality 66, Table 1; Fig. 2)]. Olalla also supposedly collected $S$. tripartitus from the mouth of the Río Aguarico, a northern (left bank) tributary of the Río Napo on the border of Ecuador and Peru (specimen in the British Museum of Natural History, see Table 1), as well as the mouth of the Río Lagartococha, a northern (right bank) tributary of the Río Aguarico in Ecuador (two specimens in the American Museum of Natural History). This would indicate that at least near to the Peruvian border, S. tripartitus extends to the north of the Río Aguarico, north of the Río Napo. However, de la Torre et al. (1995a) recorded only S. $n$. graellsi from the Río Cuyabeno (a left-bank tributary of the Río Aguarico west of the Río Lagartococha). Over 7 years during her research in the Cuyabeno Faunal Reserve, Stella de la Torre travelled frequently along the Río Lagartococha in Ecuador and was unable find any evidence indicating that $S$. tripartitus occurs there (on either bank). De la Torre (1996) stated that there "is no evidence of its presence north of the Río Napo, nor along the Ríos Aguarico, Cuyabeno and Lagartococha" (p. 88). There is a possibility that the Lagarto Cocha [sic] locality of Olalla (January 1926) listed by Hershkovitz (1977, p. 927) in fact refers to a lake of the same name south of the Río Napo. This being the case, evidence for its occurrence to the north of the Napo in Ecuador would be restricted to Hershkovitz's locality of San Francisco, and the Río Aguarico locality of Olalla, the provenance of which is given by Hershkovitz (1977) on page 927 as "Aguarico (Río)", and on page 658 as "near Aguarico, Río Napo", and is mapped on page 916 at the mouth of the Río Aguarico. Napier (1976) listed the two Olalla specimens in the British Museum with localities (labels) that are difficult to interpret (Table 1). We were unable to locate "Oriente," and the altitudes 2,000-3,000 feet cannot refer to the mouth of Aguarico (see notes in Table 1). It might be that Hershkovitz (1977) interpreted the localities from the travels of the Olalla Bros., and the possibility remains that both specimens were really collected from the south bank of the Napo, opposite the mouth of the Río Aguarico or, as would be indicated by Aquino and Encarnación (1996), from the Peruvian, right bank of the Río Aguarico.

The San Francisco locality of Hershkovitz (\#66, see Table 1; Fig. 2) remains a mystery. We were unable to locate San Francisco on maps of Ecuador, but the locality, as he plotted it on his map on page 916 in Hershkovitz (1977), is in or near to the Limoncocha Biological Reserve (north bank of the Napo) and near (opposite) the mouth of the Río Indillama. Hershkovitz $(1977,1982)$ also collected a specimen of $S$. $n$. graellsi from San Francisco, on the right bank of the Napo (locality 66, p. 927). Despite this, we conclude (see below) that it is unlikely that this species occurs south of the Napo. De la Torre (1996) recorded S. f. lagonotus between the Río Indillama and the Río Napo, and has interviewed, in different places and times, six old Secoya men who lived in the area of the Ríos Santa María and Putumayo, and all of them informed that they had never seen $S$. tripartitus in that area, only S. nigricollis.

The lack of evidence today for the occurrence of $S$. tripartitus on the right bank of the Río Lagartococha, marking the Ecuadorian frontier with Peru, indicates that its range in the interfluvium of the Ríos Napo and Putumayo in Peru is limited to the east (left bank) of the river, as indicated by Aquino and Encarnación (1996), or even further restricted, as indicated above.

De la Torre $(1996,2000)$ and Kostrub (1997) have observed golden-mantle tamarins in the Yasuní National Park, between the Ríos Yasuní and Indillama, and de la Torre (1996) confirmed the occurrence of S. tripartitus between the southern bank of the Río Tiputini and the northern bank of the Río Yasuní. Kostrub (1997) reported that "in Ecuador most, if not all, of the range of goldenmantle tamarin lies within the boundaries of the Parque Nacional Yasuní and the Reserva Indígena Huaorani..." (p. 102).

The western limits to the range of $S$. tripartitus in Ecuador are not clearly defined, but Albuja (1994) extended it as far as the middle reaches of the Ríos Tiputini and Curaray (S. f. lagonotus occurs at the headwaters of the Río Curaray), the upper Río Cononaco, and the entire basins of the Ríos Yasuní and Nashiño (Fig. 3).

Concerning the information on S. tripartitus north of the Napo in Peru, we also contemplate the possibility that this 


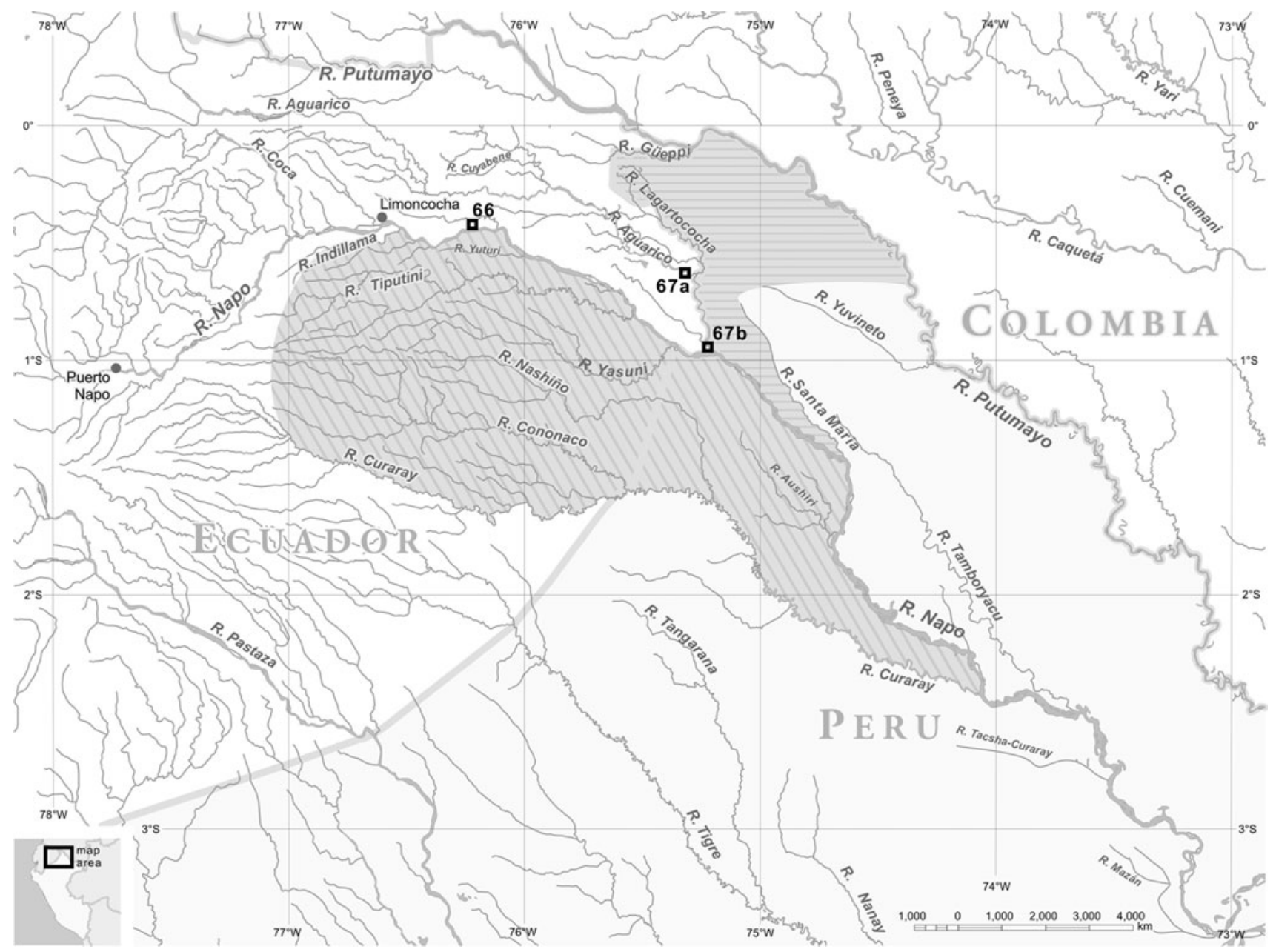

Fig. 3 Hypothetical distribution of Saguinus tripartitus. Its occurrence in the shaded area north of the Río Napo is doubtful. Map ㄷ Kellee Koenig/Conservation International

is a new taxon that is phenotypically similar to, but distinct from, S. tripartitus.

\section{Sympatry}

The question of sympatry is central to understanding the taxonomic status of $S$. tripartitus. There are three other tamarins species in the region, which, in the literature, have been considered to be partially sympatric.

\section{S. fuscicollis lagonotus (Jiménez de la Espada, 1870)}

In Peru, this saddleback tamarin occurs south of the Ríos Napo and Curaray, east to the Río Amazonas, and north of the Río Marañón (Aquino and Encarnación 1994). Hershkovitz (1977) and Tirira (2007) indicated that the western limit to its range was the Río Santiago, a north (left)-bank tributary of the Marañón. In their text, Aquino and
Encarnación (1994, p. 14) indicated its occurrence further west and south to the Río Chinchipe, although their map (p. 108) takes it only as far west as the basin of the Río Cenepa [both also north (left)-bank tributaries of the Marañón] (Fig. 4). The Peruvian range is quite well documented in terms of collecting localities, with Hershkovitz (1977) listing specimens from the Ríos Nanay, Tigre, Pastaza, and upper Santiago. Significantly, Hershkovitz (1977) gives no localities north of the Río Curaray [one at the mouth of the Curaray was collected by the Olalla Bros.1926 and presumably from the south (right bank) of the river (Heymann 2000)]. Its type locality is based on syntypes from the three localities; two in Ecuador: "La Coca, Río Napo," and "Humuyacu, Río Napo", nearby [both plotted as locality 63, Fig. XIII.4, p. 916, in Hershkovitz (1977)] and Tarapoto in Peru, a tributary of the left bank of the Napo near and on the opposite bank of the mouth of the Curaray [locality 79, Fig. XIII.4, p. 916, in Hershkovitz (1977)]. Taropoto is also a locality for $S$. $n$. 


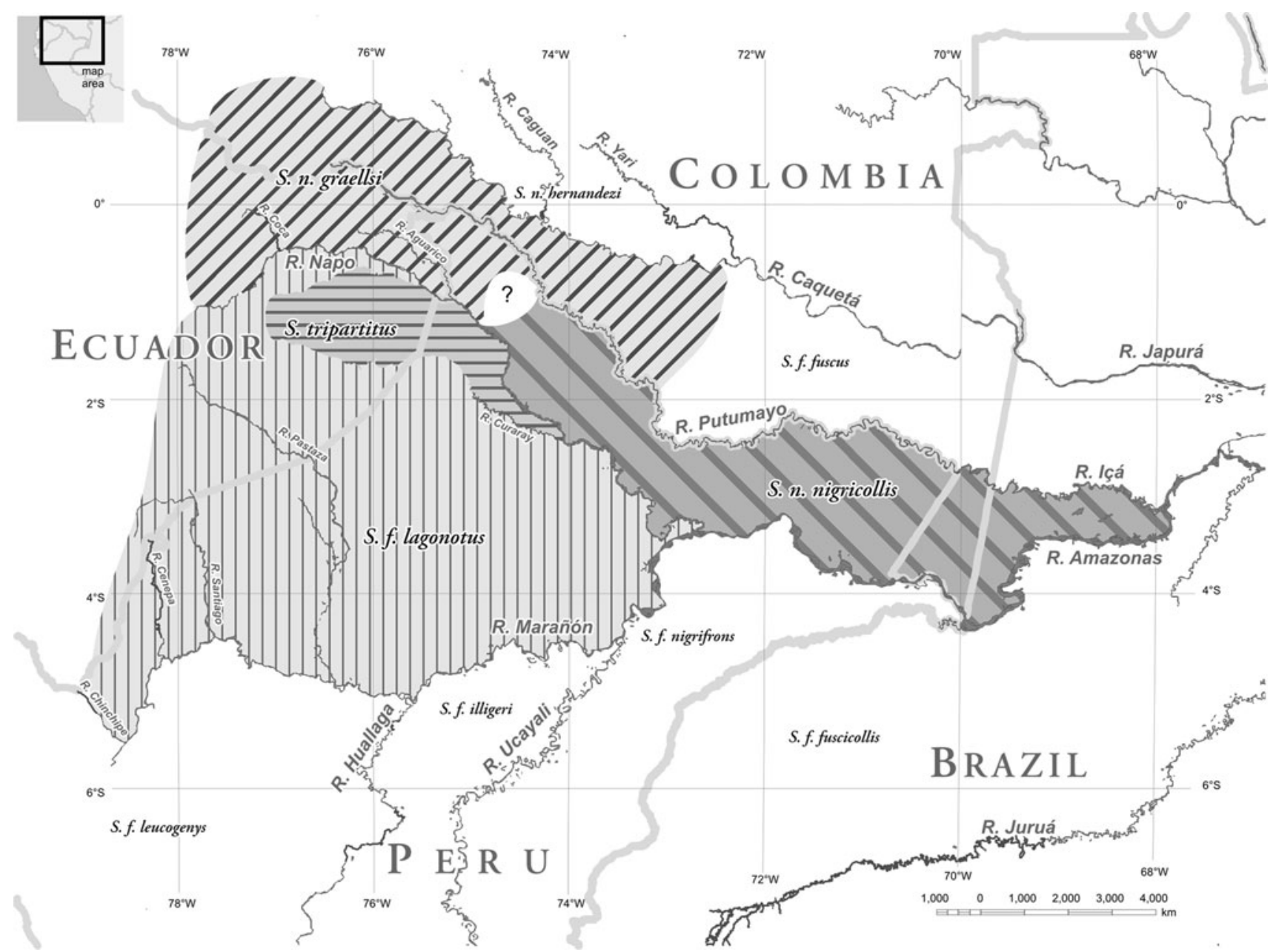

Fig. 4 Hypothetical distributions of four tamarin species in the northeastern Amazon: Saguinus nigricollis nigricollis, S. n. graellsi, $S$. tripartitus, and S. fuscicollis lagonotus. These taxa are illustrated in Fig. 5. Map @

graellsi, as is the Río Curaray, and the reason Hershkovitz (1982) indicated sympatry between $S$. n. graellsi and S. f. lagonotus. If we follow the assertion of de la Torre (1996), it does not occur in eastern Ecuador between the Ríos Curaray and Tiputini, where S. tripartitus is present. Albuja (1994), on the other hand, said that S. f. lagonotus and $S$. tripartitus were both present in the Tiputini and Tambococha localities he reported (see Table 2). The range map of $S$. f. lagonotus provided by Tirira (2007) covers the entire range of $S$. tripartitus in Ecuador, and Tirira stated (p. 119), without explanation or reference, that the two tamarin species are sympatric in the north of the range of tripartitus near the Río Napo.

It was on the basis of supposed sympatry with S. f. lagonotus (through apparently coincident collecting localities) that Thorington (1988) argued that S. tripartitus should be considered a species. The key locality for Thorington's argument of sympatry, however, was Puerto Indiana at the mouth of the Napo, but, as discussed above, Aquino and
Encarnación (1996) failed to find any evidence that $S$. tripartitus ever occurred there. Albuja (1994), however, noting that $S$. f. lagonotus was present at the two localities he recorded for $S$. tripartitus (see Table 2), supported Thorington's (1988) thesis that S. tripartitus should be considered a distinct species. De La Torre (1996), Kostrub (1997), and Heymann et al. (2002), on the other hand, found no evidence of sympatry. In Ecuador, they would apparently be sympatric south of the Río Napo, but de la Torre (1996) stated that: "To date, there are no reports of sites where any two of the (Ecuadorian) tamarin species live in sympatry" (p. 88). She observed S. f. lagonotus south of the Río Napo in areas close to the Jatun Sacha Research Station, the Añangococha Lake, and along the Pompeya Sur-Río Iro highway as far south as, but not south of, the Río Indillama, a south-bank tributary of the Napo. S. tripartitus occurs south of the Río Indillama to the Río Curaray. Heymann et al. (2002) recorded a clear separation of S. tripartitus (left bank of the Río Curaray) and S. f. lagonotus (right bank), 


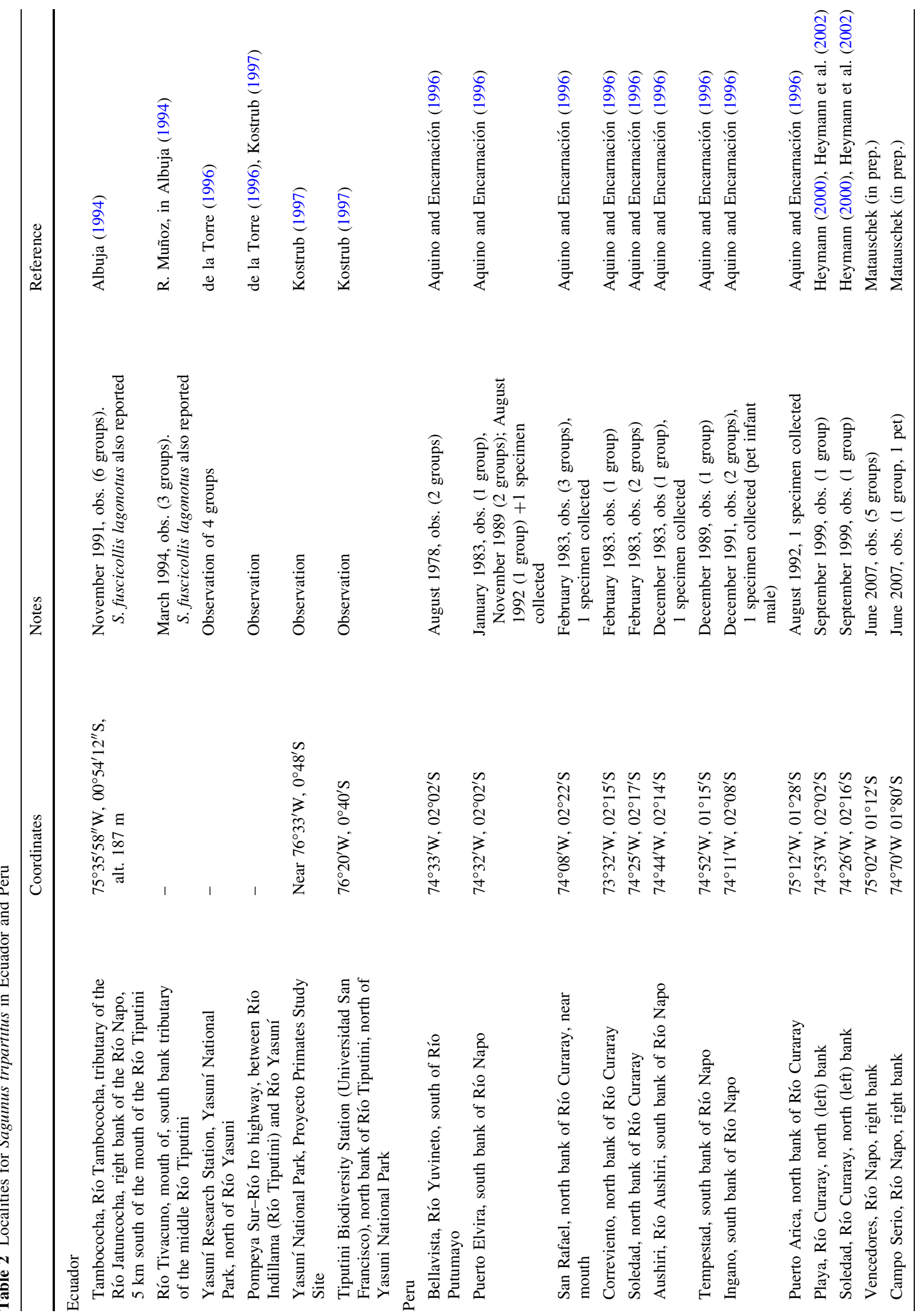




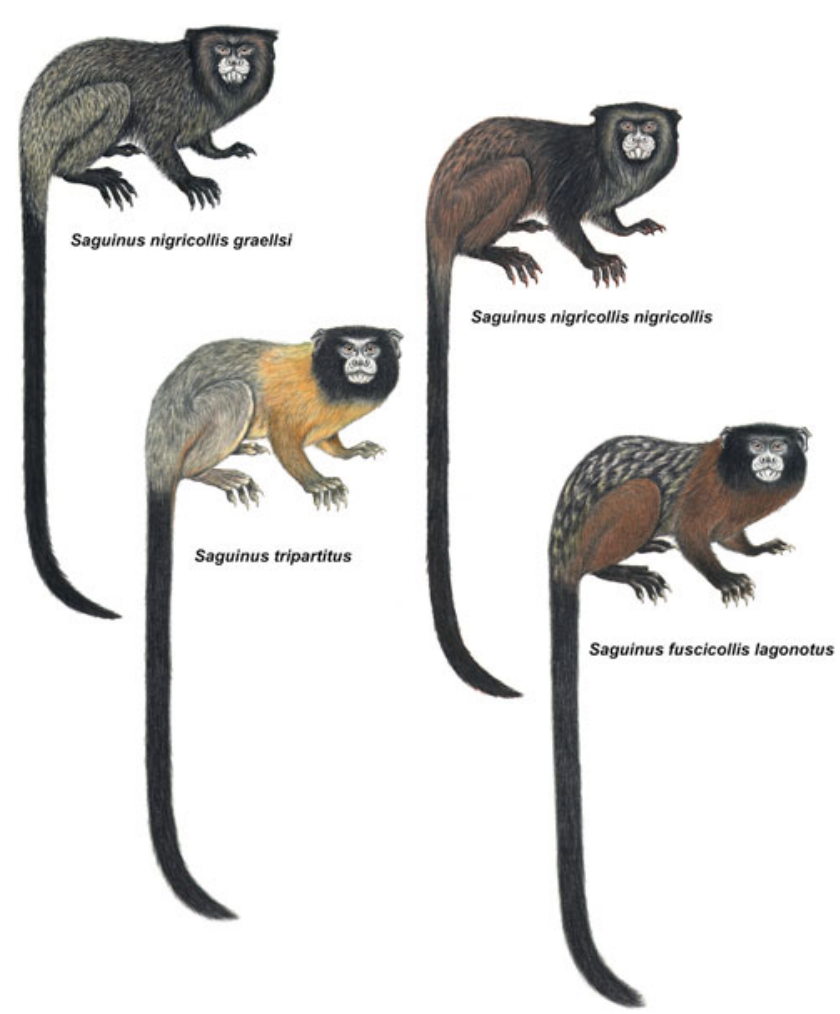

Fig. 5 Graells' black-mantle tamarin (Saguinus nigricollis graellsi), Spix's black-mantle tamarin ( $S$. nigricollis nigricollis), red-mantle saddleback tamarin (S. fuscicollis lagonotus), and the golden-mantle saddleback tamarin (S. tripartitus). Stephen D. Nash (c) Conservation International

and concluded that "The ecological similarity (of S. tripartitus) with $S$. fuscicollis and the lack of hard evidence for sympatry argue against it being a separate species" (p. 198). They agreed with Thorington (1988), however, in indicating that if $S$. tripartitus should be maintained as a distinct species, other $S$. fuscicollis subspecies should also be considered full species.

Although Aquino and Encarnación (1994) indicated that S. $n$. graellsi occurred south of the lower Napo to the Río Nanay, we believe that it is improbable (see below). We believe that the geographic ranges of $S$. f. lagonotus and S. n. graellsi do not overlap. During a survey in 2007, Matauschek (in prep.) encountered only S.f. lagonotus at all locations he visited on the right bank of the Napo, south of the Curaray in Peru. He saw both wild animals and pets (in three different villages). Also, local people clearly identified the resident tamarins on the pictures shown to them. There was no evidence for $S$. $f$. lagonotus occurring on the right bank of the Napo above the mouth of the Curaray.

\section{S. nigricollis nigricollis (Spix, 1823)}

Information on the distribution of Spix's black-mantled tamarin, S. n. nigricollis, is confused and conflicting. Its type locality is "the north bank of the Río Solimões, near São Paulo de Olivença, Amazonas, Brazil", and Hershkovitz (1977, 1982) placed it between the Ríos SolimõesAmazonas and Içá-Putumayo, at least as far west as the mouth of the Río Napo. Encarnación et al. (1990) and Aquino and Encarnación (1996) suggested its occurrence west from there along the left (north) bank of the Río Napo in Peru, upstream to the Ríos Lagartococha and Güeppi on the border with Ecuador, where according to Hershkovitz (1982) it is replaced by S. nigricollis graellsi. In a recent exploration along the Río Napo, C. Matauschek (in prep.) encountered $S$. $n$. nigricollis on the north bank of the Napo opposite San Felipe, a village $270 \mathrm{~km}$ down the Rio Napo from the Ecuadorian border, and from there further east on different locations north of the Napo and the Amazon (for example, the Ríos Ampiyacu and Apayacu, see Fig. 2). Montenegro and Escobedo (2004) saw black-mantle tamarins, which they presumed were $S$. n. nigricollis, not graellsi, between the Ríos Amazonas and Putumayo in Peru, in numerous localities they surveyed in the basins of the Río Yaguas, a south (right-bank) tributary of the Putumayo, and the Ríos Apayacu and Ampiyacu, both (left-bank) tributaries of the Amazonas (see Fig. 1).

In Colombia, Hernández-Camacho and Cooper (1976) and Defler (1994) reported that it occurs north of the Río Putumayo to the Río Caquetá and east to the Brazilian border, indicating its, as yet undocumented, presence between the Ríos Japurá and Iça in Brazil (Hershkovitz 1977, 1982). Evidence for its occurrence north of the Río Putumayo in Colombia is sparse, however. As discussed in detail by Defler $(1994,2004)$, the occurrence of $S$. $n$. nigricollis in Puerto Leguízamo (Fig. 2) was based on a specimen in the collection of the Instituto de Ciencias Naturales (ICN), registered as being from the "Quebrada El Hacha", a left (north)-bank affluent of the Putumayo (collectors H. Granados and H. Arévalo). A number of specimens in the same collection are labeled as from between the Ríos Caqueta and Putumayo. HernándezCamacho and Cooper (1976) noted, however, that "the population of the upper Putumayo River has a dull and brownish cast to the lower back and hind limbs, as well as some grizzled yellow and black in the saddle" and concluded that: "This population is thus more reminiscent of S. fuscicollis than is the lower Putumayo and Leticia population, which has a rich ferruginous cast to the lower back and hind limbs and no yellowish tones in the saddle area" (pp. 37-39). Evaluating this, Defler $(1994,2004)$ concluded that the tamarins thought to be $S$. n. nigricollis to the north of the Río Putumayo are, in fact, dull specimens of $S$. fucicollis fuscus, and recorded that Philip Hershkovitz, in a personal communication to Defler, believed the same.

South of the Río Putumayo, the range of $S$. n. nigricollis perhaps overlaps with $S$. tripartitus between the Ríos 
Yuvineto and Güeppi, as argued by Encarnación et al. (1990) and Aquino and Encarnación (1996). Bravo and Borman (2008) carried out mammal surveys at five sites between the Ríos Napo and Putumayo in Ecuador and Peru: west of the middle Río Lagartococha (Garzacocha), on the south (right) bank of the upper Río Güeppi (Güeppicillo) (both in the Cuyabeno Faunal Production Reserve in Ecuador), on the right (east) bank of the Río Lagartacocha (Redondococha) in the proposed Airo Pai Communal Reserve (Peru), the south (right) bank of the Río Güeppi in the proposed Güepi National Park (Peru), and on the upper reaches of the Río Peneya (Aguas Negras), a right-bank tributary of the Putumayo (Peru) (see Fig. 2). Bravo and Borman (2008) reported S. nigricollis in all these sites. They made no mention of subspecies, but published a photograph of an infant/juvenile (their Fig. 8A) that appears to be $S$. n. nigricollis, not graellsi. They made no mention of $S$. tripartitus.

\section{S. nigricollis graellsi (Jiménez de la Espada, 1870)}

Graells' black-mantle tamarin occurs in the upper Amazon, in southern Colombia, eastern Ecuador, and northeastern Peru. Its range is not well known, however, and our interpretation of the current evidence indicates that it is probably more restricted than is indicated by Hershkovitz (1977, 1982). The type locality is "banks of Río Napo near Tarapoto, and Destacamento, near confluence with the Marañón, Loreto, Peru" (Hershkovitz 1977). Cabrera (1958) restricted it to Tarapoto, and Hershkovitz (1977) restricted it further to "right bank Río Napo, opposite Tarapoto and above the mouth of the Río Curaray" (locality 79, p. 629). Destacamento is plotted by Hershkovitz as being on the right bank of the Río Napo, just above its mouth (locality 91, map, p. 626). The Río Tarapoto is a left-bank (north) tributary of the Río Napo.

Hernández-Camacho and Cooper (1976) wrote that in Colombia, it occurs south from the right (south) bank of the upper Río Caquetá to the ríos Sucumbíos and Putumayo on the border with Ecuador. They recorded that it could also be found in the neighborhood of Puerto Asís on the upper Putumayo, east to the vicinity of Puerto Leguízamo, north bank of the Río Putumayo. As discussed above for $S$. $n$. nigricollis, these authors indicated a probability that the form graellsi is sympatric with $S$. $n$. nigricollis in the region of Puerto Leguízamo, and Hernández-Camacho and Cooper (1976) and Hernández-Camacho and Defler (1989) and Defler (1994) listed graellsi as a full species as a result. The conclusion of Defler (1994, 2004) and Hershkovitz (pers. comm. to Defler 1994, 2004), however, was that the specimens considered to be $S$. $n$. nigricollis were in fact just dull-colored $S$. fuscicollis fuscus. In his most recent assessment, Defler (2004) listed graellsi as a subspecies of
S. nigricollis. Genetic data (Matauschek et al., submitted) support this assessment. Groves (2001, 2005) maintained graellsi as a full species based on Hernández-Camacho and Cooper's (1976) supposition of its sympatry with nigricollis.

Hershkovitz (1982) argued that there is no definite evidence for $S$. $n$. graellsi occurring north of Ecuador and suggested that black-mantle tamarins reported by Hernández-Camacho and Cooper (1976) may be either S. n. nigricollis or $S$. $n$. hernandezi. He restricted its northern limit to the Ríos Putumayo and Sucumbíos (Río San Miguel), indicating as such that it does not occur in Colombia at all.

According to Hershkovitz (1982), in Ecuador, S. $n$. graellsi extends throughout a large part of the Amazon region, south from the Ríos Putumayo and San Miguel, west to the foothills of the Andes. The altitudinal range is between 100 and 1,000 m (Hershkovitz 1982). S. n. graellsi is supposed to occur north of the Río Napo in Ecuador, and to extend east only as far the ríos Güepi and Lagartococha on the frontier with Peru (Hershkovitz 1982), where it should be replaced by $S$. n. nigricollis (see Hershkovitz 1982; Aquino and Encarnación 1996). However, in Peru, Matauschek (in prep.) encountered tamarins north of the Napo between Pantoja and Torres Causana that phenotypically matched $S$. $n$. graellsi exclusively. Consequently the border between $S$. n. graellsi and $S$. n. nigricollis must lie further southeast in Peru. The only larger river in this area is the Río Tamboryacu. The river itself seems unlikely to form a barrier for the tamarins because of its course, which is more or less parallel to the Río Napo, leaving much space for dispersal between the Putumayo and the Tamboryacu. It seems more likely that the large area of low, seasonally flooded várzea forest surrounding the vast stream network of the Tamboryacu could form a barrier for the tamarins, which are scarce and rarely seen in this type of forest. The approximate area is marked in white with a question mark in Fig. 4.

It has been recorded recently in a number of localities in northern Ecuador between the Ríos Napo and Putumayo, including the basins of the ríos Aguarico, Cuyabeno, and Pacuyacu (S. de la Torre, in litt. 1996). Borman (2002) recorded $S$. nigricollis (presumably graellsi) at Sinangoe on the Río Cofanes (a left-bank tributary of the upper Aguarico) and from the upper Río Bermejo (a right-bank tributary of the Putumayo) in Ecuador. However, it has not been found in the Yasuní National Park, covering the basin of the Río Yasuní, where it would seem that only $S$. tripartitus and, according to Albuja (1994) but not de la Torre (pers. obs. 1996), S. fuscicollis lagonotus occur.

Hershkovitz (1977) suggested that the range in Ecuador may extend as far south as the right bank of the upper Río Santiago, although in his later publication (1982), he was 
more conservative, giving the north (right) bank of the Río Pastaza as the limit. The specimens from the Ríos Pastaza and Tigre are from their uppermost reaches in Ecuador. Hershkovitz (1982) showed the four localities, numbers 19-22, on his Fig. 3 (p. 653), and listed them as follows:

(19) Yana Rumi (Río), mouth of Río Pindo Yacu, $1^{\circ} 38^{\prime} \mathrm{S}$, $76^{\circ} 59^{\prime}$ W. R. Olalla, December, 1934, February, 1935;

(20) Pindo Yacu (Río), joins Río Cunambo, upper Río Tigre at $2^{\circ} 08^{\prime} \mathrm{S}, 76^{\circ} 04^{\prime} \mathrm{W}$. R. Olalla, October, 1934, above junction with Río Cunambo at $250 \mathrm{~m}$;

(21) Pastaza (Río), $2^{\circ} 05^{\prime} \mathrm{S}, 500 \mathrm{~m}$. C. S. Webb; and

(22) Capahuara or Capihuara (Río), mouth at Río Pastaza, $2^{\circ} 03^{\prime} \mathrm{S}, 76^{\circ} 51^{\prime} \mathrm{W}$. R. Olalla, November 1934 , above mouth at $300 \mathrm{~m}$.

These are the only records south of the Río Napo in Ecuador, and the reason Hershkovitz (1982) tentatively extended the range to the entire lowland Amazonian region of Peru between the ríos Napo and Pastaza to the ríos Amazonas and Marañón. Both de la Torre (1996) and Tirira (2007) restrict $S$. $n$. graellsi to the north of the Napo in Ecuador. Tirira (2007) discounted the Pastaza and Tigre records for this species listed by Hershkovitz (1982), saying only that: "The validity of certain populations to the south of the Río Napo, in the provinces of Orellana and Pastaza, is motive for controversy" (p. 118).

Aquino and Encarnación (1994) reported, however, that $S$. $n$. graellsi has never been found along the ríos Tigre and Pastaza despite a number of primatological surveys along these rivers between 1981 and 1986. They indicated that S. n. graellsi extends eastwards from Ecuador into Peru along the right (south) bank of the Río Napo and that the range in Peru is restricted to the region between the Ríos Nanay and Napo-Curaray. Matauschek (in prep.) could find no evidence for $S$. $n$. graellsi along the Río Nanay (Santa María, Diamante Azul) in 2007 and 2008. Castro and Soini (1977) recorded only $S$. fuscicollis at the Nanay field station, just south of the river on the lower reaches. Aquino et al. (2005) surveyed the Río Aushiri (right-bank affluent of the Napo) in 2005 and in the area between the Ríos Curaray and Nashiño (left-bank affluent of the Curaray) in 2007 and 2008. They found no evidence for the presence of $S$. n. graellsi, encountering only $S$. tripartitus.

Hershkovitz (1982) gave just three localities for $S$. $n$. graellsi in Peru. Two are type localities quite distant from each other. The third is "Curaray (Río), boca (=mouth) at Río Napo" collected by Olalla and Sons in 1925. Heymann's (2000) and Heymann et al.'s (2002) finding that $S$. $n$. graellsi does not occur along either bank of the Río Curaray puts the Tarapoto and mouth of the Curaray localities (both number 4, p. 655) in doubt. Likewise, Hershkovitz (1977, p. 629) gives the (type) locality of
Destacamento as "near confluence with Marañón" but mapped it at the confluence of the Río Napo. The third Peruvian locality of Hershkovitz (1982) is listed as "Destacamento (=Francisco Orellana), Río Napo, at the junction with Río Amazonas" (Hershkovitz 1977, locality 91, p. 626; 1982, locality 5, p. 652). There is another Francisco de Orellana (Puerto), which is at the mouth of the Río Coca, an affluent of the Napo, in Ecuador (Fig. 2), a region where it would seem that $S$. $n$. graellsi certainly does occur, and which, suggestively, is also near or at (the same locality as) the type locality of $S . f$. lagonotus, also described by Jiménez de la Espada. Francisco de Orellana at the mouth of the Río Coca is also known as "Coca".

If we accept that $S . n$. graellsi is limited to the north of the Río Napo in Ecuador, does not occur between the Ríos Curaray and Napo in Ecuador or Peru, and does not occur along the right bank of the Curaray in Peru, it is very difficult to accept that it occurs between the lower Río Napo and Río Nanay in Peru. This supposition is either based on erroneous localities (either incorrect labels or incorrect interpretation of them), or, if tamarins considered to be graellsi have been seen there, that they are in fact a similar but distinct taxon.

S. n. graellsi is largely restricted to Ecuador north of the Río Napo, including the basin of the Río Cuyabeno, and probably occurring in Peru between the Ríos Napo and Putumayo west possibly as far the upper reaches of the Río Tamboryacu. Evidence for its presence in Colombia is based on a preserved specimen from the Comisaría of Putumayo, and a number of reliable sightings [for example, on the right bank of the Río Guamués, reported in Moynihan (1976), who said that their appearance conformed to the description $S$. n. graellsi provided by Hershkovitz (1966); but no specimens were obtained], and captive specimens from Puerto Asís, east to the vicinity of Puerto Leguízamo (Hernández-Camacho and Cooper 1976).

The distribution of $S$. n. graellsi has yet to be clearly defined. Hernández-Camacho and Cooper (1976) informed that in Colombia between the upper reaches of the Ríos Putumayo and Caquetá, "S. graellsi is undoubtedly sympatric with S. fuscicollis fuscus throughout its range" (p. 39), and this is confirmed by Defler (1994, 2004). It does not occur between the Ríos Curaray and Napo in Peru and Ecuador, and is not, therefore, sympatric with S. tripartitus.

\section{Sympatry, body size, and ecological niches}

In order to share the same habitat, organisms must differ in some dimension of their realized ecological niche (Putman 1994). This is true independent of whether niche 
differences are brought about through interspecific competition, predation, or other biotic interactions or whether differences result from inherently diverging fundamental niches (Keddy 1989; Putman 1994). In the context of examining the geographic distribution of different taxa from the genus Saguinus, it is appropriate to address the question of their niche differentiation and the implications for possible sympatric occurrence or exclusion.

Body size is an important life-history parameter with direct implications for the ecological niche occupied by an organism. Ecological theory considers body size as an important factor for structuring communities (Schoener 1984, 1988). It is a structuring factor for Neotropical primate communities through its implications for diet, foraging strategies, predator avoidance, locomotion, and metabolic needs (Terborgh 1983). Saguinus species, which undoubtedly live in sympatry (S. fuscicollis with S. imperator, or S. labiatus, or S. mystax), differ in body mass by $21-49 \%$ and in head-body length by $8-17 \%$ (Heymann 1997). This difference is linked to differences in locomotor style, substrate use, vertical space use and-perhaps more importantlydifferent strategies of foraging for animal prey (BiccaMarques 1999; Buchanan-Smith 1990, 1999; Garber 1991, 1993; Nickle and Heymann 1996; Nyakatura and Heymann 2010; Peres 1992; Pook and Pook 1982; Terborgh 1983; Yoneda 1981). Different prey foraging strategies in turn result in a larger divergence in the animal component of the diet between sympatric tamarin species compared with the plant component (Heymann et al. 2000; Nickle and Heymann 1996). This has been suggested as a mechanism that allows not only for sympatric coexistence but also for formation of stable mixed-species groups in tamarin monkeys (Heymann 1997; Heymann and Buchanan-Smith 2000). In contrast to the body size differences in sympatric Saguinus species, differences between doubtful sympatric taxa (S. fuscicollis lagonotus-S. tripartitus; S. fuscicollis fuscus - S. nigricollis nigricollis) amount for only $1-4 \%$ in head-body length (Heymann 1997). Head-body length is similar or identical for other taxa of the S. fuscicollis/nigricollis clade with debated sympatry (Table 3). Unfortunately, no body mass data from wild animals are available for these taxa for more detailed analyses.

When organisms occur in sympatry, they may differ in morphological, physiological, or ecological parameters more strongly than if they occur allopatrically, a phenomenon called character displacement (Schoener 1988). It can therefore be asked whether the observed differences between sympatric Saguinus species result from such character displacement or whether they are part of the fundamental ecological niche. Only one kind of datum is available for such a comparison; namely, patterns of vertical space use. The use of vertical space has been compared between $S$. fuscicollis subspecies living
Table 3 Head-body length of taxa from the Saguinus fuscicollis/ nigricollis clade with debated sympatry (source: Hershkovitz 1977, Appendix; Table 1)

\begin{tabular}{ll}
\hline Species & Measurements \\
\hline S. $n$. graellsi & $223 \mathrm{~mm}(n=5)$ \\
S. $n$. nigricollis & $223 \mathrm{~mm}(n=2)$ \\
S.f. fuscus & $226 \mathrm{~mm}(n=16)$ \\
S. tripartitus & $229 \mathrm{~mm}(n=2)$ \\
S. f. lagonotus & $232 \mathrm{~mm}(n=11)$ \\
\hline
\end{tabular}

sympatrically and allopatrically with another Saguinus species by Buchanan-Smith (1999) and Heymann (2000). The strongly similar to almost identical patterns of vertical space use of S. fuscicollis weddelli at sites where it lives sympatrically with either $S$. labiatus or S. imperator compared with sites where it occurs alone and of S. fuscicollis nigrifrons (sympatric with S. mystax) and S. fuscicollis illigeri (no sympatric congener) suggests that this is part of the fundamental niche and not influenced by the presence of a congeneric species. Examination of the few data available on vertical space use by other members of the small-bodied Saguinus clade (sensu Cropp et al. 1999; that is $S$. n. nigricollis, $S$. $n$. graellsi, $S$. $n$. hernandezi, $S$. tripartitus) also reveals similar or identical patterns of vertical space use. These taxa perform most of their activities at lower strata of the forest, as does $S$. fuscicollis (de la Torre et al. 1995b; Heymann 2000; Ulloa Vaca 1988; Vargas Tovar 1994). Qualitative and quantitative descriptions of the patterns of foraging also suggest that the different subspecies of S. fuscicollis and S. nigricollis, and S. tripartitus are also very similar or identical in this aspect (Heymann 2000; Izawa 1978; Peres 1993; Soini 1987).

In summary, we can say that: (1) all taxa of the S. fuscicollis/nigricollis clade for which information is available, be they sympatric or allopatric with another Saguinus. species, show similar or identical patterns of vertical space use; (2) Saguinus species that certainly are sympatric, even forming mixed-species groups, clearly differ in body size, whereas allopatric or doubtfully sympatric taxa have a very similar to identical body size (Table 3).

Given the similarity in vertical space use and body size of the taxa of the S. fuscicollis/nigricollis clade, it is unlikely, and for theoretical reasons implausible, that they can coexist in the same forests, even though their geographic distributions overlap.

\section{Geographic ranges, sympatry, and taxonomy of $S$. nigricollis and $S$. fuscicollis}

The definitions of these tamarin species and their range limits are, of course, hypotheses. The confusion concerning 
the geographic distributions of the northwestern Amazonian tamarins arises not only from the relatively few locality records upon which they are based (Hershkovitz was able to use five for $S$. tripartitus) but also, even when precise, the uncertainty that the labels attached to museum specimens accurately state the location where the specimens were actually obtained. As Hershkovitz (1977) fully recognized, knowing from which bank of a river a specimen was obtained is fundamental and so often can only be inferred from other locations where the species has been recorded. The collector, receiving the specimen from a hunter, may not have known or even cared to ask the exact provenance of the specimen, believing that it occurred everywhere in the region and that the base camp, even though many miles away, was sufficient reference. Many place names are confused or now difficult to identify or locate. These difficulties concerning interpretation are well known, but we also have the additional confounding factor of the definition of the species in question. For example, in a closely related group of callitrichids, the marmosets, Hershkovitz (1977) recognized six taxa in his argentata group (two species, humeralifer and argentata, each with three subspecies); today we list 14 within the geographic range he circumscribed (Rylands et al. 2008, 2009). With our understanding of the importance of rivers in demarcating the geographic distributions of so many of the Amazonian primates, it is possible to suppose that with further investigation, we would find that tamarins identified as tripartitus north of the Napo are in fact a distinct and different taxon. Lastly, we have the simple problem of assertions of the presence of a species being-unknown to the reader-based merely on the "authority" of a distribution map; considered a fact rather than a hypothesis. The numerous sources of inexactitudes have come together to confound our true understanding of the ranges of these tamarins, and our suppositions are based to a large extent on surveys that failed to find evidence of the occurrence of a species where it "should be", on our understanding of the ecology and patterns of sympatry of these small insectivore-frugivores and on distribution patterns found elsewhere in the Amazon, with geographic ranges being delimited even by minor tributaries.

Here we conclude that $S$. tripartitus occurs between the Ríos Napo and Curaray and that there is no strong evidence that it occurs in sympatry with $S$. f. lagonotus, $S$. n. nigricollis, or $S$. $n$. graellsi. The population north of the Napo around the headwaters of the Río Santa María and along the left (west) bank of the Río Yuvineto (Encarnación et al. 1990) means that it is potentially sympatric with $S$. nigricollis, but only one group was seen and further investigation is needed. It may be a distinct taxon, and we believe that sympatry is unlikely.
Concurring with other authors such as Tirira (2007), we argue that the range of $S . n$. graellsi is much smaller than was indicated by Hershkovitz $(1977,1982)$ and limited to the north of the Napo in Ecuador. This implies considerable confusion in the museum specimen localities for $S$. $n$. graellsi and the interpretation of them, as is also the case for tripartitus and lagonotus. Specimens cited by Hershkovitz from the upper Ríos Tigre and Pastaza in Ecuador require investigation (Tirira 2007). S. $n$. graellsi extends into Peru-perhaps as far as the low, seasonally flooded várzea forest surrounding the Río Tamboryacu. Beyond that would be the domain of $S$. n. nigricollis, which otherwise occurs in the middle and lower interfluvium of the Amazonas-Napo and Putumayo-Içá.

According to Defler (2004), S. n. graellsi also occurs between the upper Ríos Caquetá and Putumayo in Colombia. The middle and lower interfluvium of the Ríos Caquetá and Putumayo is otherwise occupied by S. f. fuscus. S. $n$. hernandezi extends through areas to the north of the $\mathrm{Ca}$ quetá, north to the upper Río Guaviare, and east to the Río Yari (Hernández-Camacho and Cooper 1976; Hershkovitz 1977; Defler 1994, 2004). The removal of S. tripartitus from the Napo-Putumayo interfluvium [except for the Río Yuvineto locality of Encarnación et al. (1990)] means that S. f. fuscus as such is geographically isolated from other saddleback tamarins-a reason to raise eyebrows and questions concerning its taxonomic status and even perhaps the distinction of the black-mantle and saddleback tamarin groups. The geographical proximity of $S$. f. fuscus and $S$. nigricollis is concordant with the phylogenetic affinity found by Cropp et al. (1999), who suggested that fuscus should be considered a separate species as a result-an argument also supported by Cheverud and Moore (1990) and Moore and Cheverud (1992) who studied facial morphology. Notable, however, is the sighting of S. fuscicollis on the Río Yaguas (between the Putumayo and Amazonas in Peru) by Montenegro and Escobedo (2004).

Cropp et al. (1999) were also concerned with their finding that $S$. tripartitus, considered a distinct species on the basis of sympatry with $S$. $f$. lagonotus, was, based on mitochondrial DNA (mtDNA) sequencing, phylogenetically so very close to it (sister taxa). It would seem that sympatry in this case cannot be the determining factor for considering $S$. tripartitus to be a species. Whether it should be considered again a subspecies, however, is a question that requires a review of the taxonomy of the S. nigricollis group of Hershkovitz (1977) and further research on the geographic distributions of the 17 component taxa (Rylands et al. 2008; Röhe et al. 2009).

Acknowledgments Our sincere thanks to two people who reviewed this article, one anonymous, the other Colin P. Groves, for their 
comments and wisdom. We are most grateful to Kellee Koenig, Conservation International, for drawing the maps, Figs. 1, 2, 3, and 4, and to Stephen D. Nash, Stony Brook University and Conservation International, for the illustrations of the four tamarins (Fig. 5).

Open Access This article is distributed under the terms of the Creative Commons Attribution Noncommercial License which permits any noncommercial use, distribution, and reproduction in any medium, provided the original author(s) and source are credited.

\section{References}

Albuja VL (1994) Nuevos registros de Saguinus tripartitus en la Amazonía Ecuatoriana. Neotrop Primates 2(2):8-10

Aquino R, Encarnación F (1994) Primates of Peru/Los Primates del Perú. Prim Rep (40):1-127

Aquino R, Encarnación F (1996) Distribución geográfica de Saguinus tripartitus en la Amazonía del Perú. Neotrop Primates 4(1):1-4

Aquino R, Ique C, Gálvez H (2005) Reconocimiento preliminar de la densidad y estructura poblacional de Saguinus tripartitus MilneEdwards en la Amazonía peruana. Rev Peru Biol 12:435-440

Bicca-Marques JC (1999) Hand specialization, sympatry, and mixedspecies associations in callitrichines. J Hum Evol 36:349-378

Borman AR (2002) Mammals. In: Pitman N, Moskovits DK, Alverson WS, Borman AR (eds) Ecuador: Serranías CofánBermejo, Sinangoe. Rapid biological and social inventories report 03. The Field Museum, Chicago, pp 148-152 (see also pp 210-213)

Bravo A, Borman AR (2008) Mammals. In: Alverson WS, Vriesendorp C, del Campo Á, Moskovits DK, Stotz DF, García DM, Borbor LA (eds) Ecuador-Perú: Cuyabeno-Güeppi. Rapid biological and social inventories report 20. The Field Museum, Chicago, pp 229-234 (see also pp 352-360)

Buchanan-Smith HM (1990) Polyspecific association of two tamarin species, Saguinus labiatus and Saguinus fuscicollis, in Bolivia. Am J Primatol 22:205-214

Buchanan-Smith HM (1999) Tamarin polyspecific associations: forest utilization and stability of mixed-species groups. Primates 40:233-247

Cabrera A. (1958) Catalogo de los mamíferos de América del Sur. Rev Mus Argentino de Cienc Nat "Bernardino Rivadavia" 4(1): $1-307$

Castro R, Soini P (1977) Field studies on Saguinus mystax and other callitrichids in Amazonian Peru. In: Kleiman DG (ed) The biology and conservation of the Callitrichidae. Smithsonian Institution Press, Washington, DC, pp 73-78

Cheverud JM, Moore AJ (1990) Subspecific variation in the saddleback tamarin (Saguinus fuscicollis). Am J Primatol 21:1-15

Cropp SJ, Larson A, Cheverud JM (1999) Historical biogeography of tamarins, genus Saguinus: the molecular phylogenetic evidence. Am J Phys Anthropol 108:65-89

de Ávila-Pires FD (1974) Caracterização zoogeográfica da Província Amazônica. II. A família Callithricidae e a zoogeografia Amazônica. An Acad Brasil Ciênc 46:159-181

de la Torre S (1996) Notes on the distributions of Ecuadorian callitrichids. Neotrop Primates 4:88

de la Torre S (2000) Primates de la Amazonía del Ecuador/Primates of Amazonian Ecuador. Serie Fauna del Ecuador 1. Corporación Sociedad para la Investigación y Monitoreo de la Biodiversidad Ecuatoriana (SIMBIOE), Quito

de la Torre S, Utreras V, Campos F (1995a) An overview of primatological studies in Ecuador: primates of the Cuyabeno Reserve. Neotrop Primates 3(4):169-170 de la Torre S, Campos F, de Vries T (1995b) Home range and birth seasonality of Saguinus nigricollis graellsi in Ecuadorian Amazon. Am J Primatol 37:39-56

Defler TR (1994) La conservación de primates en Colombia. Trianea (Act Cien Tecn INDERENA) 5:255-287

Defler TR (2004) Primates of Colombia. Tropical field guide series. Conservation International, Washington, DC

Encarnación F, Castro N, de Rham P (1990) Observaciones sobre primates no humanos en el Río Yuvineto (Río Putumayo), Loreto, Peru. In: La primatología en el Perú: investigaciones primatológicas (1973-1985). Proyecto Peruano de Primatología "Manuel Morro Sommo", Lima, pp 68-79

Freese C, Heltne PG, Castro R, Whitesides G (1982) Patterns and determinants of monkey densities in Peru and Bolivia, with notes on distributions. Int J Primatol 3:53-90

Garber PA (1991) A comparative study of positional behavior in three species of tamarin monkeys. Primates 32:219-230

Garber PA (1993) Feeding ecology and behaviour of the genus Saguinus. In: Rylands AB (ed) Marmosets and tamarins: systematics, behaviour, and ecology. Oxford University Press, Oxford, pp 273-295

Groves CP (2001) Primate taxonomy. Smithsonian Institution Press, Washington, DC

Groves CP (2005) Order primates. In: Wilson DE, Reeder DM (eds) Mammal species of the world: a taxonomic and geographic reference, vol 1, 3rd edn. Johns Hopkins University Press, Baltimore, pp 111-184

Hernández-Camacho J, Cooper RW (1976) The non-human primates of Colombia. In: Thorington RW Jr, Heltne PG (eds) Neotropical primates: field studies and conservation. National Academy of Sciences, Washington, DC, pp 35-69

Hernández-Camacho J, Defler TR (1985) Some aspects of the conservation of non-human primates in Colombia. Primate Conserv (6): $42-50$

Hernández-Camacho J, Defler TR (1989) Algunos aspectos de la conservación de primates no-humanos en Colombia. In: Saavedra CJ, Mittermeier RA, Santos IB (eds) La primatología en Latinoamérica. World Wildlife Fund, Washington, DC, pp 67-100

Hershkovitz P (1966) Taxonomic notes on tamarins, genus Saguinus (Callithricidae, Primates) with descriptions of four new forms. Folia Primatol 4:381-395

Hershkovitz P (1977) Living new world monkeys (Platyrrhini): with an introduction to primates, vol 1 . The University of Chicago Press, Chicago

Hershkovitz P (1982) Subspecies and geographic distribution of black-mantle tamarins Saguinus nigricollis Spix (Primates: Callitrichidae). Proc Biol Soc Wash 95:647-656

Heymann EW (1997) The relationship between body size and mixedspecies troops of tamarins. Folia Primatol 68:287-295

Heymann EW (2000) Field observations of the golden-mantled tamarin, Saguinus tripartitus, on the Río Curaray, Peruvian Amazonia. Folia Primatol 71:392-398

Heymann EW, Buchanan-Smith HM (2000) The behavioural ecology of mixed species troops of callitrichine primates. Biol Rev 75:169-190

Heymann EW, Knogge C, Tirado Herrera ER (2000) Vertebrate predation by sympatric tamarins, Saguinus mystax and Saguinus fuscicollis. Am J Primatol 51:153-158

Heymann EW, Encarnación CF, Canaquin JEY (2002) Primates of the Río Curaray, northern Peruvian Amazon. Int J Primatol 23:191-201

Izawa K (1978) A field study of the ecology and behavior of the black-mantled tamarin (Saguinus nigricollis). Primates 19:241-274

Keddy PA (1989) Competition. Chapman \& Hall, London 
Kostrub CE (1997) Preliminary field observations of golden-mantled tamarins, Saguinus tripartitus, in eastern Ecuador. Neotrop Primates 5:102-103

Montenegro O, Escobedo M (2004) Mammals. In: Pitman N, Chase Smith R, Vriesendorp C, Moskovits DK, Piana R, Knell G, Wachter T (eds) Perú: Ampiyacu, Apayacu, Yaguas, Medio Putumayo. Rapid biological and social inventories report 12. The Field Museum, Chicago, pp 164-171 (see also pp 254-257)

Moore AJ, Cheverud JM (1992) Systematics of the Saguinus oedipus group of the bare-face tamarins: evidence from facial morphology. Am J Phys Anthropol 89:73-84

Moynihan M (1976) The new world primates: adaptive radiation and the evolution of social behavior, languages, and intelligence. Princeton University Press, Princeton

Napier PH (1976) Catalogue of the Primates in the British Museum (Natural History). Part I. Families Callitrichidae and Cebidae. British Museum (Natural History), London

Neville MK (1976) Census of primates in Peru. In: Pan American Health Organization (ed) First Inter-American Conference on Conservation and Utilization of American Nonhuman Primates in Biomedical Research. Pan American Health Organization, Washington, DC, pp 19-29

Nickle DA, Heymann EW (1996) Predation on Orthoptera and other orders of insects by tamarin monkeys, Saguinus mystax mystax and Saguinus fuscicollis nigrifrons (Primates: Callitrichidae), in northeastern Peru. J Zool Lond 239:799-819

Nyakatura JA, Heymann EW (2010) Effects of support size and orientation on symmetric gaits in free-ranging tamarins of Amazonian Peru: implications for the functional significance of primate gait sequence patterns. J Hum Evol 58:242-251

Peres CA (1992) Prey-capture benefits in a mixed-species group of Amazonian tamarins, Saguinus fuscicollis and S. mystax. Behav Ecol Sociobiol 31:339-347

Peres CA (1993) Diet and feeding ecology of saddle-back (Saguinus fuscicollis) and moustached (S. mystax) tamarins in Amazonian terra firme forest. J Zool Lond 230:567-592

Pook AG, Pook G (1982) Polyspecific association between Saguinus fuscicollis, Saguinus labiatus, Callimico goeldii and other primates in north-western Bolivia. Folia Primatol 38:196-216

Putman RJ (1994) Community ecology. Chapman \& Hall, London

Röhe F, Silva JS Jr, Sampaio R, Rylands AB (2009) A new subspecies of Saguinus fuscicollis (Primates, Callitrichidae). Int J Primatol 30:533-551
Rylands AB, Mittermeier RA, Silva JS Jr, Heymann EW, de la Torre S, Kierulff MCM, Noronha MdeA, Röhe F (2008) Marmosets and tamarins. Pocket identification guide. conservation international tropical pocket guide series. Conservation International, Arlington

Rylands AB, Mittermeier RA, Coimbra-Filho AF (2009) The systematics and distributions of the marmosets (Callithrix, Callibella, Cebuella, and Mico) and callimico (Callimico) (Callitrichidae, Primates). In: Ford SM, Davis LC, Porter L (eds) The smallest anthropoids: the marmoset/callimico radiation. Springer, New York, pp 25-61

Schoener TW (1984) Size differences among sympatric bird-eating hawks: a worldwide survey. In: Strong DR Jr, Simberloff D, Abele LG, Thistle AB (eds) Ecological communities: conceptual issues and the evidence. Princeton University Press, Princeton, pp 254-281

Schoener TW (1988) Ecological interactions. In: Myers AA, Giller PS (eds) Analytical biogeography. Chapman \& Hall, London, pp 255-297

Soini P (1987) Ecology of the saddle-back tamarin Saguinus fuscicollis illigeri on the Rio Pacaya, northeastern Peru. Folia Primatol 49:11-32

Terborgh J (1983) Five new world primates. Princeton University Press, Princeton

Thorington RW Jr (1988) Taxonomic status of Saguinus tripartitus (Milne-Edwards, 1878). Am J Primatol 15:367-371

Tirira D (2007) Guía de campo de los mamíferos del Ecuador. Publicación especial sobre los mamíferos del Ecuador 6 . Ediciones Murciélago Blanco, Quito

Ulloa Vaca R (1988) Estudio sinecológico de primates en la Reserva de Producción Faunística Cuyabeno. Amazonía Ecuatoriana. Tesis de Licenciado, Pontificia Universidad Católica del Ecuador, Quito

Vargas Tovar N (1994) Activity patterns of Saguinus nigricollis hernandezi at the Tinigua National Park, Colombia. Field Studies on New World Monkeys, La Macarena. Colombia 9:23-31

Yoneda M (1981) Ecological studies of Saguinus fuscicollis and Saguinus labiatus with reference to habitat segregation and height preference. Kyoto Univ Overseas Res Rep New World Monkeys 2:43-50 